This item was submitted to Loughborough's Research Repository by the author.

Items in Figshare are protected by copyright, with all rights reserved, unless otherwise indicated.

\title{
Role of urban design and planning in disaster risk reduction
}

\section{PLEASE CITE THE PUBLISHED VERSION}

http://dx.doi.org/10.1680/udap.13.00011

\section{PUBLISHER}

(C) ICE Publishing

\section{VERSION}

VoR (Version of Record)

\section{LICENCE}

CC BY-NC-ND 4.0

\section{REPOSITORY RECORD}

Chmutina, Ksenia, Tamar Ganor, and Lee S. Bosher. 2019. "Role of Urban Design and Planning in Disaster Risk Reduction”. figshare. https://hdl.handle.net/2134/14256. 
This item was submitted to Loughborough's Institutional Repository (https://dspace.lboro.ac.uk/) by the author and is made available under the following Creative Commons Licence conditions.

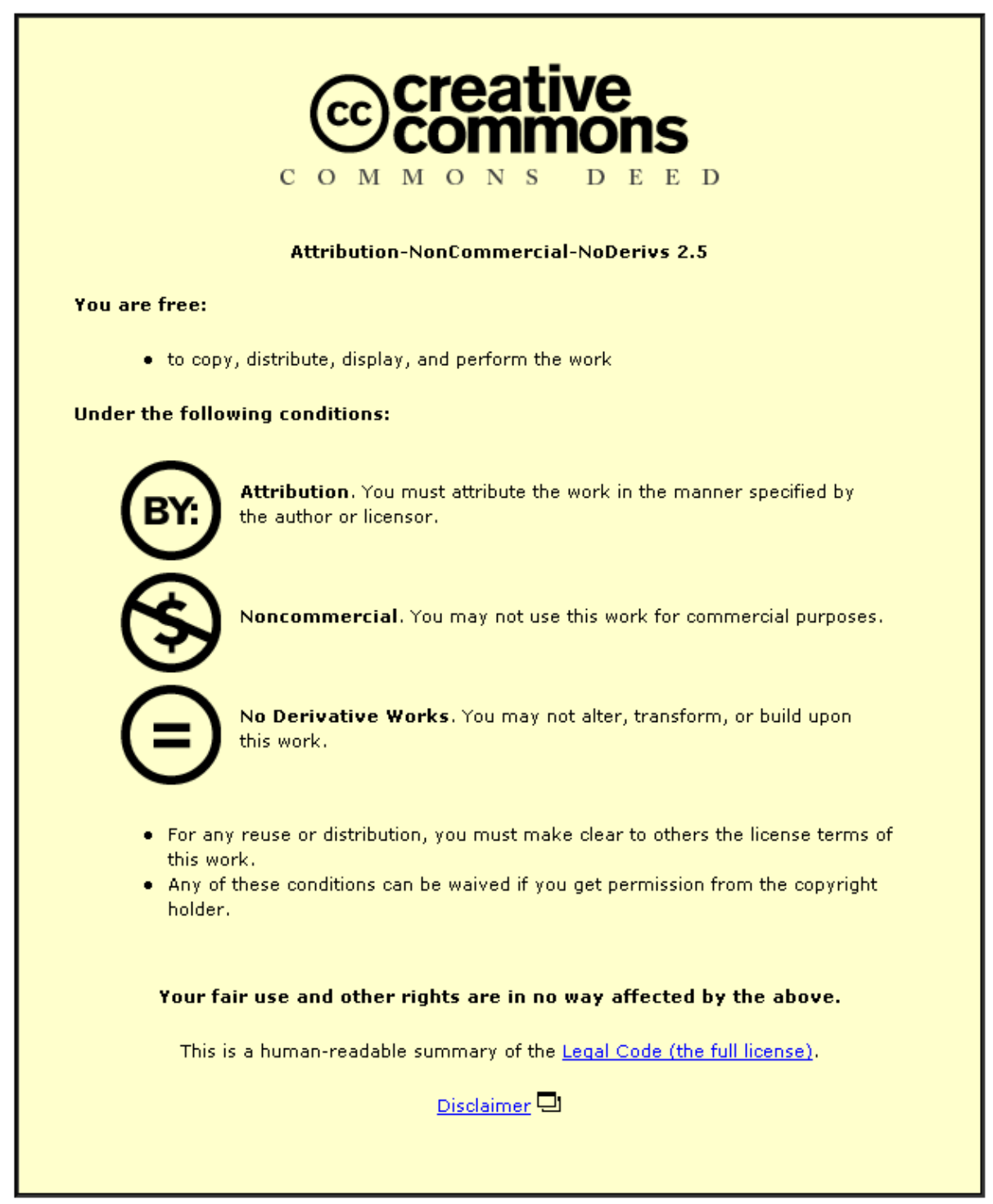

For the full text of this licence, please go to: http://creativecommons.org/licenses/by-nc-nd/2.5/ 


\section{Role of urban design and planning in disaster risk reduction}

1 Ksenia Chmutina MA, PhD Research Associate, School of Civil and Building Engineering, Loughborough University, UK

2 Tamar Ganor MA, MEd

GIS Coordinator, Bezalel Academy of Arts and Design, Jerusalem, Israel
3 Lee Bosher BSC, PgC, PhD, FRGS, FHEA Senior Lecturer, School of Civil and Building Engineering, Loughborough University, UK
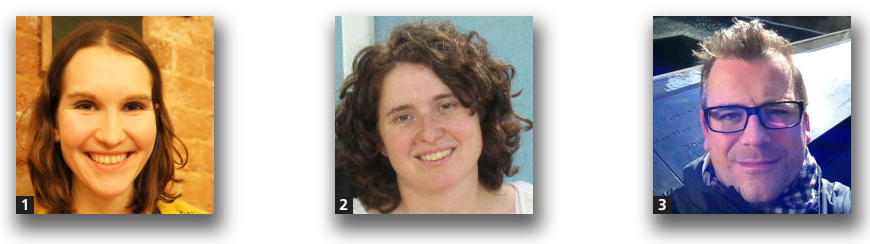

Recent disasters in cities worldwide have highlighted the fragility of built environments to a range of hazards and increased concerns about the resilience of cities, with contemporary discussions considering how physical/protective interventions can be integrated into the built environment. It is important for the numerous stakeholders involved with the construction industry to take responsibility for integrating disaster risk reduction (DRR) activities into the planning, (re)design, construction and operation of the built environment. It is fundamentally important to understand which stakeholders should be involved and when their inputs are needed. Utilising two case studies in Jerusalem and Nottingham the role of key stakeholders in the integration of DRR activities into the urban design and planning process is evaluated. It is argued that there is a general lack of consensus regarding the roles of stakeholders and their levels of participation. This paper identifies the commonalities and differences between key stakeholders who should be responsible for integrating DRR activities into urban design and planning and emphasises the gaps in stakeholders' involvement. It is argued that there is a need to engage construction stakeholders with a wider range of stakeholders who are typically not extensively involved in DRR, and ensure interaction among them.

\section{Introduction}

There is a global concern about the increasing complexity of disasters and the impacts they have on society and the environment. The UN definition of 'disasters' particularly highlights the fragility and vulnerability of the built environment.

A serious disruption of the functioning of a community or a society involving widespread human, material, economic or environmental losses and impacts, which exceeds the ability of the affected community or society to cope using its own resources. Disasters are often described as a result of the combination of: the exposure to a hazard; the conditions of vulnerability that are present; and insufficient capacity or measures to reduce or cope with the potential negative consequences. Disaster impacts may include loss of life, injury, disease and other negative effects on human physical, mental and social well-being, together with damage to property, destruction of assets, loss of services, social and economic disruption and environmental degradation. (UNISDR, 2007b)
It is thus important to recognise that disasters often occur because risk reduction measures have not been considered or undertaken, despite there being previous knowledge of existing hazards and threats (Bosher, 2014). In order to reduce disaster risks, disaster risk reduction (DRR) approaches have been proposed that can systematically analyse and manage the causal factors of disasters 'through reduced exposure to hazards, lessened vulnerability of people and property, wise management of land and the environment, and improved preparedness for adverse events' (UNISDR, 2011).

DRR can be seen as an ongoing cycle of interrelated activities, by which governments, businesses and communities plan and reduce the impact of disasters, react during a disaster and take action to recover after a disaster has occurred (Thayaparan et al., 2010). DRR measures should be seen as a continuous process, with resilience being methodically built into the design, construction and operation processes (DCOP), rather 
than added on to a construction project as an 'afterthought' (Bosher et al., 2007a).

Spatial planning is increasingly becoming an attractive and important tool for DRR, as it presents an opportunity to regulate the long-term use of space through which exposure to natural hazards and human-induced threats can be minimised (Sutanta et al., 2010). In order to protect societies and economies it is important to understand the sensitivity of the built environment and the necessity to adapt it to the impacts of a multitude of hazards and threats. This can be achieved through pro-active DRR measures implemented during DCOP by the construction professionals, whose knowledge and experience, it is argued, fits into DRR approaches (Bosher et al., 2007a). The involvement of construction professionals in DRR has in the past largely been associated with a range of critical activities such as temporary shelter before and after the disaster and restoration of public services (e.g. hospitals, schools, power lines) and so on (World Bank, 2001). In reality, however, construction experts have a much broader role to anticipate, assess, prevent, prepare, respond and recover (Keraminiyage et al., 2007). Pena-Mora (2005) makes a valuable point that construction professionals have a key role to play in DRR because they are involved in the construction of the infrastructure, and therefore should also be involved when infrastructure is destroyed by an event.

Other professions should not be underestimated either, as multistakeholder participation can increase the capacity and capability of those who take part in DRR. Involvement of various public and private stakeholders can also lead to and facilitate knowledge and experience sharing. It is essential to identify those stakeholders who can have a positive influence over DRR in the built environment at various stages of DCOP, including commissioning, operation and maintenance (Mojtahedi and Oo, 2012), as decision making requires an integrated understanding of how to avoid and mitigate the effects of risks and disasters.

This paper sets out to understand which stakeholders should be involved and when they should optimally be involved. Based on two international case studies in Jerusalem, Israel and Nottingham, England, it discusses the role of key stakeholders in the integration of DRR activities in DCOP, as well as identifying the commonalities and differences between the key stakeholders who should be responsible for integrating DRR measures at specific stages of DCOP and emphasising the gaps in stakeholders' involvement.

Section 2 of this paper gives an overview of stakeholders' involvement in DRR and gives an introduction to the construction process in England and Israel. Section 3 provides a methodological overview, and Section 4 discusses the context of the case studies. Section 5 outlines stakeholder involvement, while Section 6 presents conclusions.

\section{Incorporation of DRR into DCOP}

\subsection{Stakeholders in DRR}

The definition of a stakeholder dates back to the 1980s, when Freeman (1984) explained that a stakeholder can be an individual or a group who can have an effect, or is influenced by the goals and objectives of an institution. Harrison et al. (2010) define stakeholders as those who play decision-making roles, and who take advantage of those decisions. Based on these definitions, Mojtahedi and Oo (2012) propose that in order to reduce disaster risk in the built environment, it is the responsibility of stakeholders to cope with the devastating impact of disasters effectively; therefore the involvement (and non-involvement) of various stakeholders has to be carefully considered in DRR.

UNISDR (2007a) sees multi-stakeholder participation as an important DRR mechanism, as it leads to coordination, analysis and advice on areas of priority among a multiplicity of organisations and individuals working at various levels of governance. Stein and Edwards (1999: p. 244) define the multistakeholder platform as 'decision making bodies (voluntary or statutory) comprising different stakeholders who perceive the same resource management problem, realise their interdependence for solving it, and come together to agree on action strategies for solving the problem'.

However, despite the fact that the role of multiple stakeholders is important for effective DRR, literature that comprehensively explains the involvement of various stakeholders in DRR is scarce, particularly with regard to DCOP. Djalante (2012) discusses a lack of technical support and exchange between local stakeholders. Thayaparan et al. (2010) mention stakeholders that should be involved in disaster reconstruction projects, with the particular emphasis on local government, as it has a power to monitor, control and guide reconstruction work. Mileti (1999), Ofori (2004) and Bosher and Dainty (2011) also underline the importance of the construction sector in minimising the adverse impacts of disasters through hazard mitigation. Traditionally, two types of hazard mitigation are considered (Bosher et al., 2007b).

- Structural mitigation, such as the strengthening of the buildings or infrastructure that is exposed to hazards. This can be done using various engineering design and construction practices as well as building codes.

- Non-structural mitigation, such as relocating existing developments or directing new developments away from known hazard locations, maintaining protective features of the natural environment, public awareness raising, professional training and so on.

The construction sector can play an important role in structural mitigation, while non-structural mitigation can be influenced by planners and developers. 


\subsection{DRR in DCOP}

DCOP in England can best be described using the stages suggested by the Royal Institute of British Architects (RIBA) 'plan of work', which is a definitive model for the building design and construction process (RIBA, 2007). (Although current RIBA stages are being revised and were changed in 2013 (RIBA, 2012), the new proposed stages are not dramatically different, and the changes would not affect the results of this paper.) The process starts with the 'preparation' and 'appraisal' and continues through the pre-construction and construction stages to the 'change of use', when the whole process starts again. Five project stages and phases are detailed in Table 1.

It is important to note that not all stakeholders have to be involved/are involved in every stage of the process due to the professional remits. The aim of this paper is to demonstrate the difference between the reality (who is involved) and the best practice (who should be involved) in DRR activities, and at what stage.

While RIBA stages cover DCOP, they do not provide any indication of the stages at which DRR measures should best be implemented. Bosher et al. (2007a) suggest the following aligning of the DRR with generic design/planning and building phases (see Figure 1).

Figure 1 demonstrates that it is important to identify and determine the risks of a particular hazard/threat (or number of hazards/threats) on a chosen site during the preparation and early design stages when the decision is made on why, what and where to build. While in the best case scenario the ways of reducing the identified risks are also discussed, it is highly unlikely that this would take place at the early stages of DCOP. Therefore the measures to reduce the risks and to choose the most suitable DRR measures should be incorporated during the pre-construction phases when not only non-structural but also structural DRR measures can be implemented. If new hazards/threats emerge during the construction and post-construction phases, or during the change of use, all stages have to be reviewed again.

\section{Methodology}

This paper is a continuation of the study conducted by Bosher et al. (2007a), in which the UK construction stakeholders and their involvement in the DRR process is described. The aim of this paper is to present similar findings but on a more local

\begin{tabular}{lll}
\hline Stage & Stage name & Generic phases \\
\hline 1 & Preparation & $\begin{array}{l}\text { Appraisal } \\
\text { Design briefing }\end{array}$ \\
& \\
& & \\
& Design & Concept \\
& & Design development \\
& Technical design
\end{tabular}

3

Pre-construction phases

Product information Tender documentation Tender action
Project planning (mobilisation) Construction to practical completion Post-practical completion
Stage description

Identification of client's needs and objectives, business case and possible constraints on development. Identification of procurement method, procedures, organisational structure and range of consultants and others to be engaged for the project.

Outline proposals for structural and building services systems, outline specifications and preliminary cost plan. Development of concept design to include structural and building services systems, updated outline specifications and cost plan. Application for detailed planning permission. Preparation of technical design(s) and specifications.

Preparation of detailed information for construction. Preparation and/or collation of tender documentation. Identification and evaluation of potential contractors and/or specialists for the project.

Issuing of information to the contractor. Provision to the contractor of further information as and when reasonably required. Review of information provided by contractors and specialists.

Administration of the building contract after practical completion and making final inspections. Assisting building user during initial occupation period. Review of project performance in use.

Table 1. Planning, design and construction stages 


\begin{tabular}{|c|c|c|c|c|c|}
\hline \multirow{2}{*}{$\begin{array}{l}\text { Generic } \\
\text { planning/ } \\
\text { design/build } \\
\text { phases }\end{array}$} & \multicolumn{2}{|c|}{ Pre-project phases } & \multirow[b]{2}{*}{ Pre-construction phases } & \multirow[b]{2}{*}{ Construction phases } & Post-completion phases \\
\hline & Preparation & Design & & & Use \\
\hline \multirow{4}{*}{ DRR inputs } & Hazard id & cation & & Hazar & ntification review \\
\hline & \multicolumn{4}{|c|}{ Mitigative adaptations } & \\
\hline & & & \multirow{2}{*}{\multicolumn{2}{|c|}{ Preparedness planning }} & $\begin{array}{l}\text { Preparedness planning (including } \\
\text { response) }\end{array}$ \\
\hline & & & & & Recovery planning \\
\hline
\end{tabular}

Figure 1. Disaster risk reduction (DRR) activities aligned with generic planning, design and construction stages

scale. The case studies presented in the paper are Nottingham and Jerusalem. The selected case studies are a part of an ongoing 4-year EU-funded project (Desurbs; for more details, go to http://www.desurbs.eu/), which examines the design and planning of safer urban spaces and is engaged in developing lessons and recommendations for the practice community.

The research employed a qualitative case study methodology, including online survey and semistructured face-to-face interviews, as well as a review of the relevant literature. For each of the case studies, extensive preliminary data regarding the hazard and threats in the case study city were collected.

Interviewees represented a range of stakeholders directly or indirectly involved in DCOP. They were asked to fill in the matrix in order to indicate their opinion on the involvement of other stakeholders in DRR during DCOP. This opinion was then compared with the real situation. During the interviews the stakeholders were encouraged to discuss their choices.

As this study is qualitative in focus, looking in depth at a relatively small number of case studies and responses is not statistically accurate and only provides empirical evidence. However, it highlights the gaps in stakeholders' engagement and allows improved understanding about the relative importance of stakeholders' collaboration in DRR activities during DCOP.

\section{Case studies description}

A diverse number of threats to the building environment exists in Nottingham and Jerusalem, including both extreme natural and human-induced hazards.

\subsection{Overview of hazards and threats in Nottingham (England)}

Flooding is arguably one of the greatest natural hazards that poses direct risks to urban areas in Nottingham. Nottingham is located in the East Midlands region of England and has a history of flooding dating back to 1795. The current flood defences were built after serious flooding in 1947 affected $45 \mathrm{~km}$ of road, 3000 properties and 86 factories in the city centre. After further significant flood events in 1998 and 2000, the UK government's Environment Agency worked with partner organisations to study the flood risk over the entire length of the River Trent and its main tributaries (Nottingham and Nottinghamshire Local Resilience Forum, 2011). The findings were published in the fluvial Trent strategy (EA, 2005), which showed that the existing defences offered a relatively low standard of protection compared with the latest best practice recommendations. Based on this work the Environment Agency prepared and started work to reduce flood risk by building the Nottingham left bank flood alleviation scheme. The $£ 51$ million flood alleviation scheme aims to reduce the risk of flooding to 16000 homes and businesses along a $27 \mathrm{~km}$ stretch of the River Trent, from Sawley to Colwick (Figure 2). It also provides additional protection to key infrastructure at the heart of the communities along this stretch of the Trent.

Currently, the probability of flooding across Nottingham is about $1 \%$ ( 1 in 100 chance) in any given year.

Other natural hazards that affect Nottingham include severe weather such as storms and gales, low temperatures and heavy snow, heat waves and drought (Cabinet Office, 2010).

However, not all problems in Nottingham are of natural origin; between 2000 and 2003 the press and other media claimed Nottingham was the 'gun-crime capital of the UK', and was dubbed 'Shottingham' in some areas (Alderson and Copping, 2007; Doward, 2007). A crime survey by Reform (Gibbs and Haldenby, 2006) states that Nottingham topped the crime rankings for police statistics on murders, burglaries and vehicle crime, and had almost five times the level of crime 


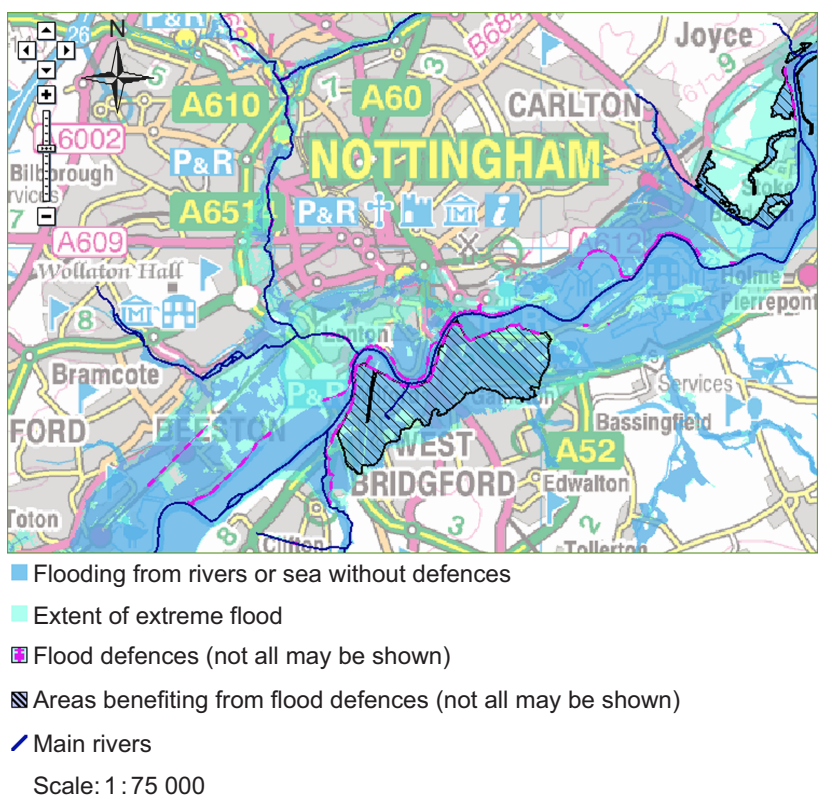

Figure 2 Flood map for Nottingham (Source: Environment Agency information (c)2013)

as the safest town in the rankings'. While the crime figures in the city are relatively high for England, initiatives introduced to tackle the levels of crime appear to have had an effect, with a 2006 Home Office survey showing that the overall level of crime in the city was down by $12 \%$ since 2003 (Nottingham City Council, 2006). Initiatives include the community and neighbourhood protection service developed by Nottingham City Council, Nottinghamshire police and Nottingham city homes to take an uncompromising stance towards antisocial behaviour. While Nottingham is not prone to other man-made hazards, due to the high level of crime and its impacts on the community, the authors as well as the interviewed stakeholders (as will be described later) see crime reduction as a part of the DRR.

\subsection{Overview of hazards and threats in Jerusalem, Israel}

Similarly to Nottingham, Jerusalem is also prone to both natural and man-made hazards. In terms of natural hazards, earthquakes receive the most attention. Most of the city was built before 1980, a year when earthquake standards were incorporated into building regulations. In addition, many of the buildings that can potentially be damaged by earthquakes are closely built and based on older stratas and landfills, thus enhancing instability. Some of these areas include national and international heritage sites, and improving their resilience involves many aspects in addition to design, planning and building issues (Israeli Science and Technology National Committee, 2011).
Not only in Israel but also worldwide, Jerusalem has a unique status that makes it a target for man-made threats. Its religious and political importance has enhanced vulnerabilities in the urban area, especially in landmark perimeters, which include conservation monuments such as the Stone Temple, Church of the Holy Sepulchre and the Western Wall, and government buildings such as the Prime Minister's official residence and the house of parliament - the Knesset. These high-profile sites have been used numerous times as spaces for public activity such as rallies and demonstrations as well as targets for terrorist attacks (Figure 3). As the governance sites are well protected (Pedahzur and Paran, 2003), terrorist attacks have often struck Jerusalem in many public areas, which are easy to access and host a large volume of people (Savitch, 2005).

\section{Stakeholder involvement: who is involved, why, when?}

\subsection{Overview of the stakeholders" involvement in England and Israel}

The identification of stakeholders in the built environment depends on the phase of the project (Mojtahedi and Oo, 2012), but the generic set of stakeholders includes local government,

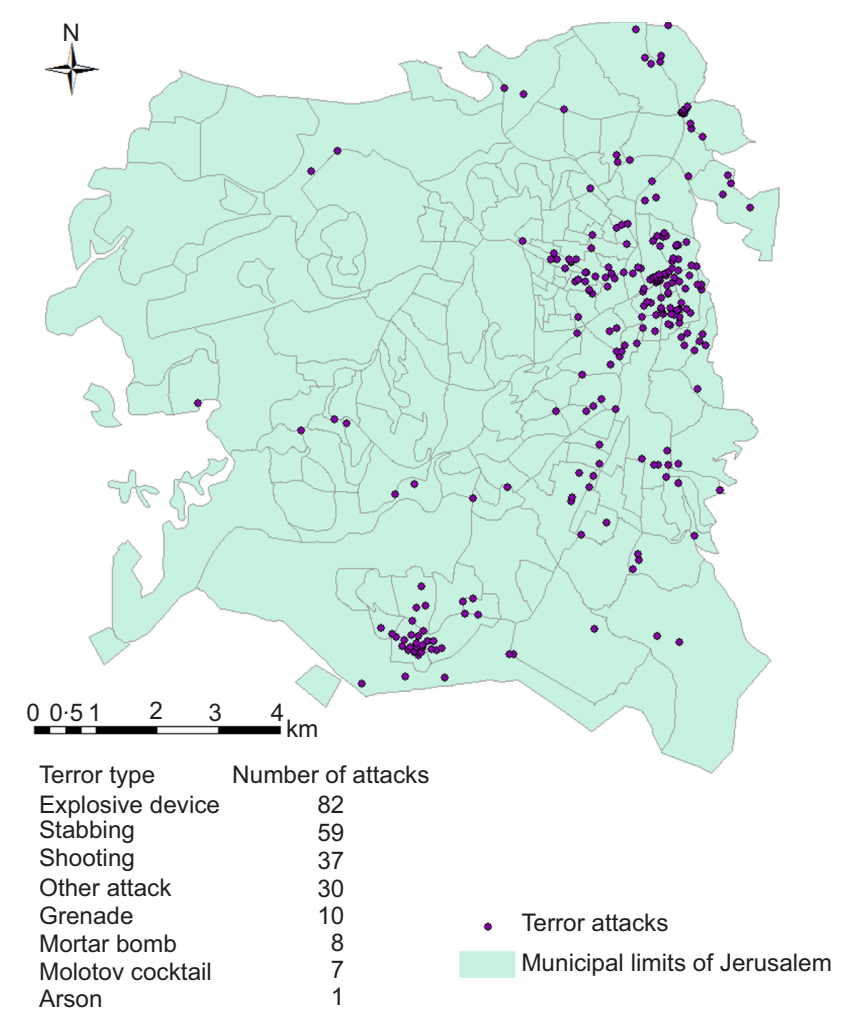

Figure 3. The map of terrorist attacks in Jerusalem in 1990-2002 
contractors and subcontractors, suppliers, financial institutions, insurance companies, and the affected local community. Stakeholders involved in DRR are generally defined in various laws and regulations that cover the responsibilities of different agencies, institutional arrangements and execution of operational procedures. Their structure and hierarchy depends on the government system, but in most cases governmental laws and regulations are required to provide directives for local government action (Sutanta et al., 2010).

In England (as part of the UK) the integration of DRR measures in urban planning and DCOP is starting to receive increasing attention. For example, the Civil Contingencies Act 2004 (Civil Contingencies Secretariat, 2004) requires local authorities in England to produce a multi-hazard/threat risk assessment. It also places a legal duty on local authorities and other key agencies to maintain the local risk assessments in a community risk register (Cabinet Office, 2010), which is a basis for supporting the preparation of emergency plans and appropriate decisions regarding urban planning. The Civil Contingencies Act puts in place a framework that enables a wide range of stakeholders to be involved with emergency management planning; however, the broader process within DRR measures is not encouraged, neither does it give a clear perspective on the extent to which construction professionals are involved in this framework (Bosher et al., 2007b).
In contrast to England, there are no legislative requirements for local governments to incorporate security and resilience into urban spaces in Israel (Pedahzur and Paran, 2003). However, there is legislation to incorporate a protected space inside buildings to defend them from the effects of warfare (Knesset, 1965). Legislative and regulation bodies in Israel have not identified risk mitigation as a needed inherent phase of planning and construction. The only risk type that is formally surveyed as part of the planning and building process is environmental hazards. While no formal arrangements are in place to coordinate stakeholders involved in emergency planning and preparedness, such as that which resulted from the Civil Contingencies Act in England, a similar network of relationships between various stakeholders has been partially established in general guidelines; however, it is not executed properly during real-time events and not practised thoroughly (Ministry of Public Security, 2012).

Table 2 lists stakeholders that have formal input regarding the integration of DRR activities in pre-construction and construction phases in Israel and England. There is a great resemblance between the stakeholders involved in pre-construction and construction phases in England and Israel. For example, the involvement of local authorities is obvious in both cases: this involvement is essential and it has been emphasised in the Incheon Declaration (Prevention Web, 2009), which stated the importance

\begin{tabular}{|c|c|c|}
\hline DCOP stage & England & Israel \\
\hline Pre-construction & $\begin{array}{l}\text { Urban planners/designers } \\
\text { Client } \\
\text { Developer } \\
\text { Civil and structural engineers } \\
\text { Emergency/risk managers } \\
\text { Local authorities } \\
\text { Contractors } \\
\text { Utilities companies } \\
\text { Material suppliers }\end{array}$ & $\begin{array}{l}\text { Local and national planning and building committee } \\
\text { Local municipality's engineer } \\
\text { Construction inspector } \\
\text { Various government agencies (environmental, health etc.) } \\
\text { Home Front Command } \\
\text { Infrastructure authorities and utilities } \\
\text { Local licensing authority } \\
\text { Emergency authorities }\end{array}$ \\
\hline Construction & $\begin{array}{l}\text { Architects/designers } \\
\text { Civil/structural engineers } \\
\text { Contractors } \\
\text { Utilities companies }\end{array}$ & $\begin{array}{l}\text { Architects } \\
\text { Engineers } \\
\text { Clients } \\
\text { Project manager/developer } \\
\text { Planners } \\
\text { Construction engineer } \\
\text { Systems planner } \\
\text { Safety advisor } \\
\text { Contractors and subcontractors } \\
\text { Internal inspector } \\
\text { Execution inspector }\end{array}$ \\
\hline
\end{tabular}

Table 2. List of stakeholders involved in integration of disaster risk reduction activities in design, construction and operation processes 
of local governments in DRR. It is also clear that while construction sector stakeholders are crucial in implementing structural measures, a wider set of stakeholders has a positive impact on non-structural elements. However, there are some unique characteristics to the way DRR measures are implemented in the case studies. This is discussed in detail in the next section.

\subsection{Stakeholders' involvement in the case study cities}

Figures 4 and 5 demonstrate the real and anticipated involvement of private and public stakeholders in DRR during DCOP; that is, which stakeholders are or should be involved, and at what stage. While these results do not represent statistical accuracy due to the small size of the respondents' sample, they enable the identification of general similarities and differences in the involvement of the key stakeholders at different stages of DCOP, as well as seeing the perceived importance and formality of these inputs. It is important to note that in both cases some stakeholders are only involved in particular stages of DCOP rather than the whole process as a result of their professional remits.

In both cases, architects were perceived to be the most important construction sector stakeholder, who could provide essential inputs into DRR throughout DCOP. It was suggested that other significant stakeholders were clients, developers and engineers. Planners and emergency services stakeholders were perceived as not being involved in some of the phases; however, it was admitted that they should have a bigger input in DRR, particularly during the design and pre-construction phases. Both cases allocate only a small role to trade organisations and representatives, insurers and the general public. End-users were also perceived as a non-important stakeholder. Academic literature often argues (e.g. Djalante, 2012) that end-users should be involved, but the empirical evidence drawn from the case studies provides a different picture: while it may be a theoretical concern, stakeholders do not think that end-users should play a big role (if any) in DRR decisions. This may be explained by the possibility that the end-user is not necessarily known during the earlier stages of the DCOP; for example, it may not be clear what companies are going to occupy the space in office developments.

The biggest difference in the two case studies lies in the involvement of government agencies and local authorities. This dissimilarity is evident throughout DCOP: despite the fact that there are policies supporting and encouraging the involvement of local authorities in DRR activities in England, the evidence

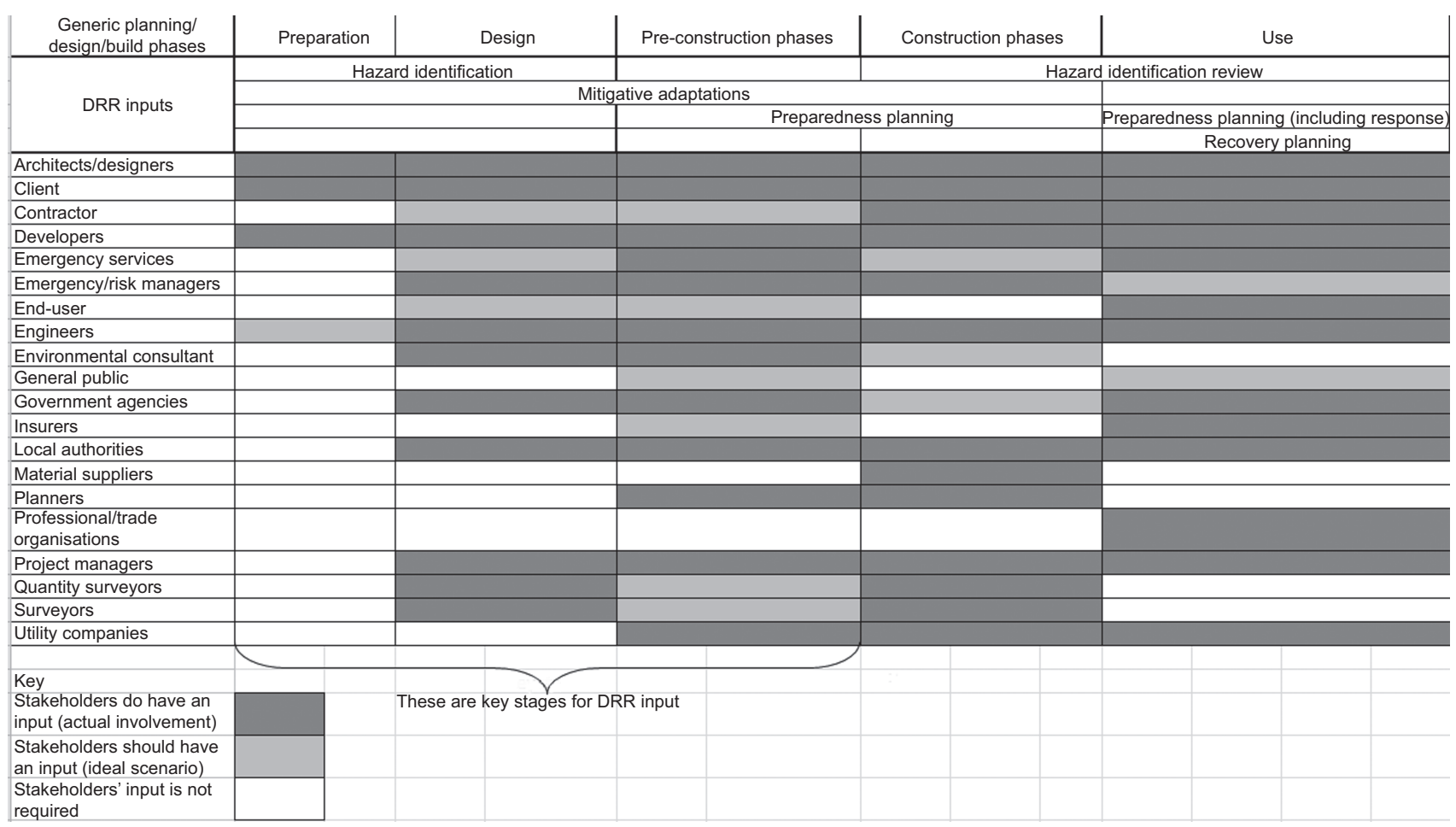

Figure 4. Illustration of multiple stakeholder inputs into disaster risk reduction (DRR) activities in Nottingham, England, aligned with generic design, construction and operation process stages 


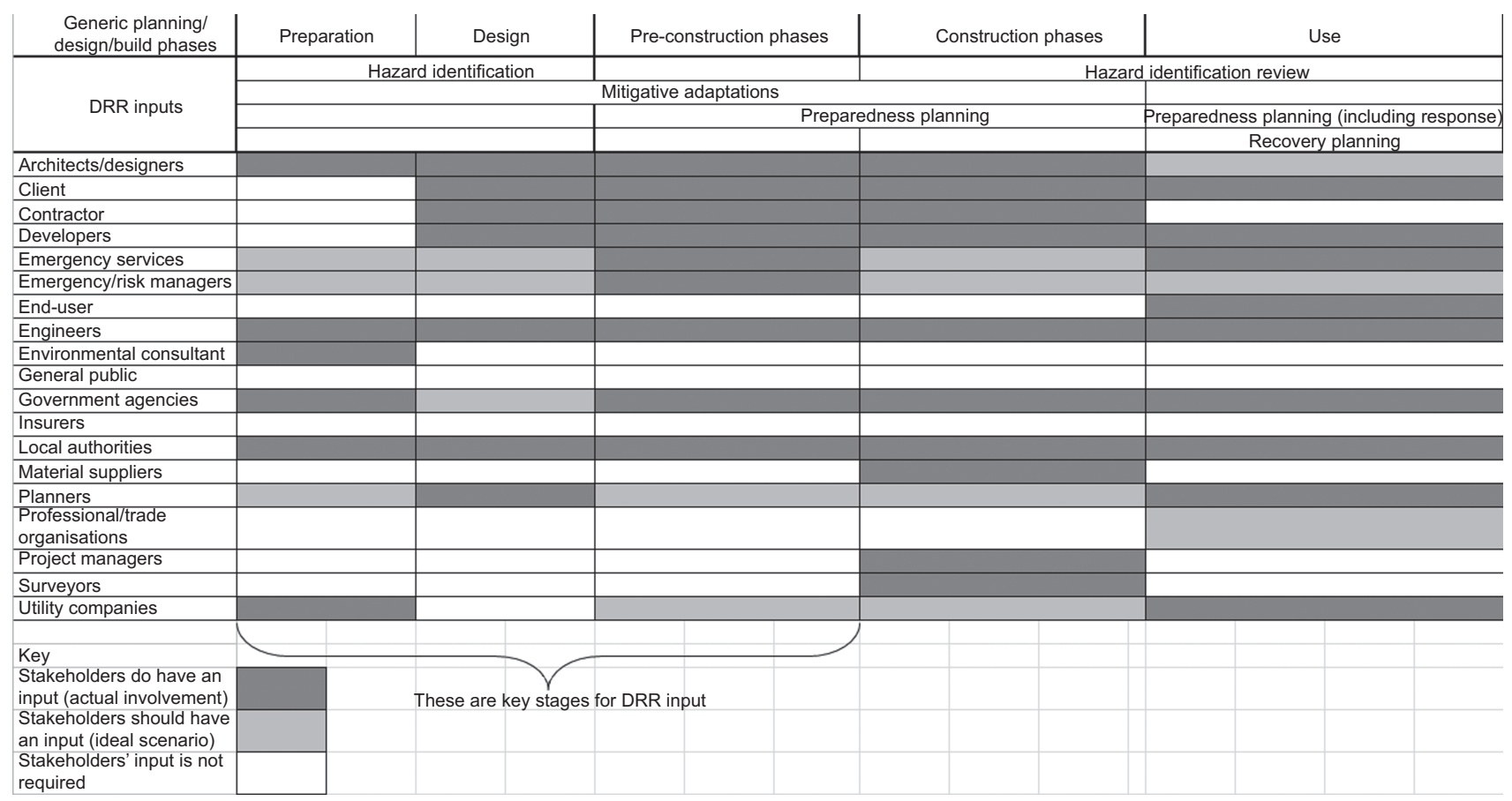

Figure 5. Illustration of multiple stakeholder inputs into disaster risk reduction (DRR) activities in Jerusalem, Israel, aligned with generic design, construction and operation process stages

in Figure 4 suggests that Nottingham local authorities are engaged in DRR only if they are expected to be. On the contrary, they are seen as important stakeholders with formal specified roles and are involved in all the stages of the process in Jerusalem. A good example of the involvement of the governmental agencies is the role played by the Home Front Command (HFC), which is perceived to be one of the main actors in DRR activities. (As only generic stakeholders' groups are presented in Figures 4 and 5, the HFC is included in the 'governmental agencies' group of stakeholders.) The HFC does not have an equivalent in England. The HFC is a military branch in charge of defending and managing civilians during times of crisis (HFC, 2013). It sees itself as the only non-political mechanism during the process of planning permissions, as they do not represent (and thus cannot be influenced by) construction stakeholders, the private sector or government bodies.

Another big difference is in the involvement of environmental consultants, who, in the case of Nottingham, are seen as an integral part of DRR and are suggested to play an even bigger role during the crucial stages of design and pre-construction. In Jerusalem, they are only involved at the first stage, and it is suggested that their involvement should end there; however, this may soon change because, according to some of the interviewees, the environmental practices are slowly being implemented in the public agenda.

Overall, during the process of data collection, it became clear that there is an apparent disconnect between the stakeholders who should be involved and those who are involved in reality. In addition, although some of the stakeholders are involved in DRR, their inputs are not always formal and clear.

In terms of the time of the involvement, Figures 4 and 5 suggest that the crucial phase of the negotiation and implementation of DRR measures is during the first three stages of the process, as has been described in Table 1 and emphasised in Figure 1 (preparation, design and pre-construction). However, while the early phases of DCOP are understood as being essential for DRR, stakeholders' engagement does not necessarily take place. For example, Figure 4 shows that emergency services are not necessarily involved until the construction phase, when it can be too late to implement DRR measures that have not been considered, thus making them more expensive but less effective. The situation can also be to the contrary if any unnecessary DRR measures have been installed. 
The preparation phase is suggested to be largely ignored, particularly in the case of Nottingham, where only stakeholders directly involved in the construction process (e.g. architects, engineers, client) have an input. It would, however, be beneficial to the project if more stakeholders were involved, as during the preparation stage developers can discuss the project with a number of agencies in order to identify and address any areas of conflict, and thus ensure that the application goes smoothly (While and Howe, 2005). Importantly, issues resolved at this stage are also less time consuming and costly. However, little discussion takes place in reality, mainly due to a perceived deficit of knowledge about the possible solutions and their effects, or about the bodies that can highlight potential barriers.

Most involvement occurs (and should occur) during the design, pre-construction and construction phases, with both private and public stakeholders playing various roles. The pre-construction phase was identified by the stakeholders as the critical phase in DCOP when DRR should be integrated. Figures 4 and 5 demonstrate that the majority of the stakeholders are involved in this phase; however, the large number of the stakeholders involved does not guarantee the successful and effective implementation of DRR. This is due to the lack of interaction between the agencies involved. There is a lack of a clear workflow in everyday functions, as well as a methodical disregard of official protocol during emergencies, as acknowledged by some of the respondents in both case study cities. Despite the official emergency protocols being constantly updated, they are not sufficiently practised. Another reason for the lack of implementation of DRR is the lack of capacity; for example, despite the fact that the HFC has the capability to be more engaged in DRR and is theoretically required to participate in the local building committees, the main challenge is the lack of capacity due to the lack of human resources. Similar situations are also a reality in Nottingham, where local authorities lack financial resources and thus personnel to be more proactively engaged in DRR activities with the construction sector. Efforts have been made in Nottingham towards encouraging the cooperation of various stakeholders. For instance, Fisher et al. (2012) report that the local resilience forum consists of multi-agency partnerships made up of representatives from local public services, including the emergency services, local authorities, the NHS, the Environment Agency and other government and non-governmental agencies. However, while many stakeholders find this mechanism useful, it faces such challenges as funding, inter-agency communication, lack of decision-making and so on. In addition, the members of the local resilience forum do not necessarily include a large number of construction stakeholders (Fisher et al., 2012).

A wide range of stakeholder inputs occurs during the construction phase. This is, however, not the most crucial phase of DCOP with regard to DRR, because (in the best case scenario) any DRR measures should have already been taken into account. Similarly, consideration of DRR during the postcompletion phase is an 'afterthought'; however, in the case of retrofit or change of use, it is crucial for stakeholders to reconsider the risks and use this opportunity to improve the DRR measures.

\section{Conclusions}

The objective of this paper was to identify the key stakeholders who are or should be responsible for integrating DRR measures into DCOP, and discuss the gaps in stakeholders' involvement. This paper emphasises the need to engage construction stakeholders with a wider range of stakeholders, who are typically not extensively involved in DRR, and ensure interaction among them.

A number of recent extreme weather events and man-made threats have shown that timely and effective reactive measures (i.e. emergency response and recovery) are not sufficient in keeping the built environment safe; it is vital to deal with hazards and threats proactively, with a wide range of stakeholders being involved.

It is acknowledged that although there are limitations to using a two-city/country case study approach, the results presented here are nonetheless indicative of the reality (in contrast to the rhetoric) of multi-stakeholder approaches to incorporating DRR into urban design and planning. Accordingly, five main conclusions can be drawn from the responses.

- It is clear that in both cities there is a lack of consensus on the roles of the stakeholders and the level of participation in DRR activities. The data collection process showed that there is a degree of disagreement as to whether a stakeholder should or should not be involved in a particular stage of DCOP. For example, some of the interviewees believed that while urban planners and designers are highly involved in the process, they should play a much smaller role and only participate in the pre-project phase and postcompletion phase with regard to DRR.

- There is also evidence that various stakeholders are not sufficiently informed about who is and who is not involved in DRR activities and who might provide a valuable insight into the most appropriate DRR measures. These issues should be resolved as lack of knowledge about participants decreases the effectiveness of measures. In addition, it is important to engage the end-users and general public by providing specific support to enhance the awareness of DRR as well as to encourage participation at the grassroots level.

Despite the presence of the legislation for integrating DRR into DCOP, many stakeholders have no practical experience in dealing with DRR. At the same time, many of the planning procedures and regulations are not known by 
stakeholders outside the planning departments. Many of the stakeholders involved in the early stages of the project crucial for DRR measures lack information about the possible options. This indicates that there may be a need to integrate DRR principles into the core professional training (or at least continued professional development) of some of these key stakeholders.

The legislation used in the construction sector suffers from the absence of clear policy when it comes to the integration of DRR measures in both case study countries, and does not always allow stakeholders involved in DCOP to obtain a clear view of the full extent of the norms that apply to the DRR activities in construction.

When taking both DCOP stages and DRR into account, it becomes clear that the pre-construction phase is critical in the design-construction-operation process, and it is at this stage that the the DRR measures should be instigated. Despite the fact that construction stages and integrated security and resilience framework stages are not comparable, they can be aligned in order to inform the stakeholders about the possible options of incorporating DRR measures.

The engagement of a wider set of stakeholders in DRR during DCOP is important as the information and knowledge of various stakeholders about the risks and impacts of a particular hazard can be assessed and incorporated into the concept of the project, thus leading to the most effective and efficient strategy in DRR.

The limitation of this study is realised as only empirical evidence of the local-level stakeholders' engagement was demonstrated; therefore, no specific recommendations can be provided at this stage. In addition, various contexts will require various solutions. Nonetheless, it is clear that the incorporation of DRR into DCOP can benefit from an implementation of the framework that supports various stakeholders in making informed decisions in the pro-active implementation of DRR.

\section{Acknowledgements}

This article has drawn from empirical work collected through the EU Framework 7 security project Designing Safer Urban Spaces (DESURBS). The authors would also like to thank Professor Mike Turner for the insightful comments on an early draft of the paper.

\section{REFERENCES}

Alderson A and Copping J (2007) Police joined dark side to regain Nottingham. Daily Telegraph, 5 August 2007.

Bosher L (2014) Built-in resilience through disaster risk reduction: operational issues. Building Research and Information 42(2): 240-254.

Bosher LS and Dainty ARJ (2011) Disaster risk reduction and 'built-in' resilience: towards overarching principles for construction practice. Disasters: The Journal of Disaster Studies, Policy and Management 35(1): 1-18.

Bosher L, Dainty ARJ, Carrillo P and Glass J (2007a) Built-in resilience to disasters: a pre-emptive approach. Engineering, Construction and Architectural Management 14(5): 434- 446.

Bosher L, Dainty A, Carrillo P, Glass J and Price A (2007b) Integrating disaster risk management into construction: a UK perspective. Building Research and Information 35(2): 163-177.

Cabinet Office (2010) National Risk Register of Civil Emergencies, 2010 edn. HMSO, London, UK.

Civil Contingencies Secretariat (2004) Civil Contingencies Act 2004: A Short Guide. Cabinet Office, London, UK.

Djalante R (2012) Adaptive governance and resilience: the role of multi-stakeholder platforms in disaster risk reduction. Natural Hazards and Earth System Sciences 12(9): 2923 2942.

Doward J (2007) Brutal ganglord who fell victim to his own drugs. The Observer, 5 August 2007.

EA (Environment Agency) (2005) Fluvial Trent Strategy. Environment Agency, London, UK.

EA (2013) Risk of Flooding from Rivers and Seas: Nottingham. Interactive map. See http://www.environment-agency.gov. uk/homeandleisure/floods/31652.aspx (accessed 31/05/2013).

Fisher J, Harre-Young SN and Bosher L (2012) Understanding the relationship between resilience and sustainability: emergency planning and the design of urban space. In Proceedings of REAL CORP 2012 Re-mixing the City Towards Sustainability and Resilience? (Schrenk M, Popovich VV and Zeile P (eds)). Schwechat, Austria, pp. 965-973.

Freeman RE (1984) Strategic Management: A Stakeholder Approach. Pitman, Boston, MA, USA.

Gibbs B and Haldenby A (2006) Urban Crime Rankings. See http://reform.co.uk/client_files/www.reform.co.uk/files/ urban_crime_rankings.pdf (accessed 31/05/2013).

Harrison JS, Bose DA and Phillips RA (2010) Managing for stakeholders, stakeholders utility function, and competitive advantage. Strategic Management Journal 74(1): 58-74.

HFC (Home Front Command) (2013) http://www.oref.org.il/ International/14-en/PAKAR aspx (accessed 31/05/2013).

Israeli Science and Technology National Committee (2011) Protocol No. 78. See http://www.knesset.gov.il/protocols/ data/rtf/mada/2011-01-17.rtf. (accessed 31/05/2013) (in Israeli).

Keraminiyage KP, Amaratunga RDG and Haigh RP (2007) Role of construction in managing disasters in developing economies. Proceedings of Annual Bank Conference on Developing Economics. The World Bank, Bled, Slovenia.

Knesset (1965) Israel Planning and Construction Law. See http:// www.moit.gov.il/NR/exeres/D129ACB3-7445-4F76-8225FC2D9BFAEB34.htm (accessed 31/05/2013) (in Israeli). Mileti D (1999) Disasters by Design: A Reassessment of Natural 
Hazards in the United States. Joseph Henry Press, Washington DC, USA.

Ministry of Public Security (2012) The Minister of Public Security's Response to the State Comptroller's Report on the Mt. Carmel Fire. See http://mops.gov.il/english/ aboutusenglish/news/pages/ministerresponsecarmelfire. aspx (accessed 11/02/2014).

Mojtahedi MSH and Oo BL (2012) Stakeholders' approaches towards natural disasters in built environment: a theoretical framework. In Proceedings of the 28th Annual ARCOM Conference (Smith SD (ed.)), 3-5 September, Edinburgh, UK. Association of Researchers in Construction Management, pp. 133-142.

Nottingham City Council (2006) Some Facts About Crime in Nottinghamshire. Nottingham City Council, UK.

Nottingham and Nottinghamshire Local Resilience Forum (2011) Community Risk Register. 3.7 ed. Nottingham and Nottinghamshire Local Resilience Forum, Nottingham, UK. Ofori G (2004) Construction Industry Development for Disaster Prevention and Response. National University of Singapore. See http://www.grif.umontreal.ca/pages/i-rec\%20papers/ ofori.pdf (accessed 31/05/2013).

Pedahzur A and Paran G (2003) Terror in Jerusalem. Jerusalem Institute for Israeli Studies, Israel.

Pena-Mora W (2005) Collaborative First Response to Disaster Involving Critical Physical Infrastructure. O’Neal Faculty scholar seminar, University of Illinois, UrbanaChampaign, IL, USA.

Prevention Web (2009) Incheon Declaration on Disaster Risk Reduction in Asia and the Pacific 2010. UNISDR AP. See http://www.preventionweb.net/english/professional/ publications/v.php?id=16327 (accessed 29/05/2013).

RIBA (Royal Institute of British Architects) (2007) The Architect's Plan of Work. RIBA, London, UK.

RIBA (2012) RIBA Plan of Work 2013: Consultation Document. See http://www.architecture.com/Files/ RIBAProfessionalServices/Practice/FrontlineLetters/ RIBAPlanofWork2013ConsultationDocument.pdf (accessed 29/05/2013).

Savitch HV (2005) An anatomy of urban terror: lessons from Jerusalem and elsewhere. Urban Studies 42(3): 361-395.

State Comptroller and Ombudsman (2010) Carmel Fire Report. See http://www.mevaker.gov.il/serve/contentTree. asp?bookid5616\&id52\&contentid5\&parentcid5undefined\& sw51366\&hw5698 (accessed 29/05/2013).

Stein NA and Edwards VM (1999) Platforms for collective action in multiple-use common-pool resources. Agricultural and Human Values 16(3): 241-255.

Sutanta H, Rajanifard A and Bishop ID (2010) Integrating spatial planning and disaster risk reduction at the local level in the context of spatially enabled government. Proceedings of the GSDI 12 World Conference: Realising Spatially Enabled Societies, Singapore.
Thayaparan M, Siriwardena ML, Amaratunga RDG, Kaklauskas A and Lill I (2010) Reforming HEI to improve skills and knowledge on disaster resilience among construction professionals. Proceedings of the Construction, Building and Real Estate Research Conference 2010, Paris, France.

UNISDR (United Nations Office for Disaster Risk Reduction) (2007a) Guidelines: National Platform for Disaster Risk Reduction. See http://www.unisdr.org/we/inform/ publications/601 (accessed 29/05/2013).

UNISDR (2007b) Terminology. See http://www.unisdr.org/we/ inform/terminology\#letter-d (accessed 27/01/2014).

UNISDR (2011) GAR: Global Assessment Report on Disaster Risk Reduction: Revealing Risk, Redefining Development. See http://www.preventionweb.net/english/hyogo/gar/2011/ en/home/download.html (accessed 29/05/2013).

While I and Howe J (2005) Unpacking the barriers to sustainable urban drainage use. Journal of Environmental Policy and Planning 7(1): 25-41.

World Bank (2001) India: World Bank and Asian Development Bank Complete Preliminary Gujarat Earthquake Damage Assessment and Recovery Plan. See http://reliefweb.int/ report/india/india-world-bank-and-asian-developmentbank-complete-preliminary-gujarat-earthquake (accessed 29/05/2013)

\section{WHAT DO YOU THINK?}

To discuss this paper, please email up to 500 words to the editor at journals@ice.org.uk. Your contribution will be forwarded to the author(s) for a reply and, if considered appropriate by the editorial panel, will be published as discussion in a future issue of the journal.

Proceedings journals rely entirely on contributions sent in by civil engineering professionals, academics and students. Papers should be 2000-5000 words long (briefing papers should be 1000-2000 words long), with adequate illustrations and references. You can submit your paper online via www.icevirtuallibrary.com/content/journals, where you will also find detailed author guidelines. 